\title{
An orthogonal zone between the Equatorial and South Atlantic margins: relevance and control in the evolution of the Afro-Brazilian basins
}

\author{
Renato M. Darros de Matos ${ }^{1}$, Ian Norton ${ }^{2}$, Ekaterina Casey ${ }^{3}$, Ana Krueger ${ }^{4,5}$ \\ 1. Nandy Oil and Gas, Rio de Janeiro, RJ, Brazil; 2. Institute for Geophysics, The University of Texas at Austin, Austin, TX, United States;3. \\ Actus Veritas Geoscience LLC, Houston, TX, United States. 4. University of Houston, Houston, TX, 5. Bluware Inc, Houston, TX, United \\ States.
}

\section{Copyright 2019, SBGf - Sociedade Brasileira de Geofísica}

This paper was prepared for presentation during the $16^{\text {th }}$ International Congress of the Brazilian Geophysical Society held in Rio de Janeiro, Brazil, 19-22 August 2019.

Contents of this paper were reviewed by the Technical Committee of the $16^{\text {th }}$ International Congress of the Brazilian Geophysical Society and do not necessarily represent any position of the SBGf, its officers or members. Electronic reproduction or storage of any part of this paper for commercial purposes without the written consent of the Brazilian Geophysical Society is prohibited.

\section{Abstract}

The Late Jurassic-Early Cretaceous rifting between South America and Africa is diachronic, and so is the insertion of oceanic crust. Strain partitioning was strongly influenced by the Proterozoic heritage and plate dynamics, leading to variations in the timing and local components of extension, transtension and localized transpression, with timing being controlled by structural partitioning of the margins. Our multidisciplinary study used spatiotemporal kinematic indicators, which led us to define five Tectonic Stages and five main Structural Segments of the South Atlantic based on deformation partitioning along the margin from Demerara/Guinea to Walvis Ridge/Rio Grande Rise. Major differences between the Equatorial and South Atlantic margins have been extensively analyzed by many authors. The Proterozoic terrains composed by the Borborema Province and part of Africa (Orthogonal Zone) have played a fundamental role, preventing and postponing the link between the Equatorial and South American rift branches, with the consequent development of distinct buffer zones in space and time.

\section{Introduction}

We used an extensive database of African and Brazilian sedimentary basins integrated with plate reconstructions (from the Plates Project - UT Austin), high resolutionsatellite-derived gravity data, to discuss a new conceptual model of South Atlantic opening based on plate tectonic reconstructions and spatiotemporal kinematic indicators. We demonstrate that different types of inheritance from Proterozoic terrains have controlled deformation partitioning through diachronous rifting events during the opening. We recognize a wide-variety of lithospheric extensional modes along South Atlantic margin ranging from hyperextended magma-poor to magma-rich, and/or to magma-poor with sharply necked margin segments. Besides using multiple methodologies to date the main tectonostratigraphic events, we use as a basis the Cretaceous time-scale ICS 2016/12 adopted by Petrobras and their published stratigraphic charts.

\section{The Proterozoic Heritage}

West Gondwana was the result of an orogenic collage of diversified terranes during the Brasiliano/Pan African orogenies and produced one of the main structures of West Gondwana (Figure 1); the 3000 km-long Trans-Saharan (TSL) lineament and its southward continuation, the Transbrasiliano Lineament (TBL), extending from NE Brazil, $3000 \mathrm{~km}$ to Argentina (Cordani et al., 2013). One quite striking feature is the Borborema Compressional Horsetail Splay (BHS) (Figure 1: made of the Borborema Province and parts of the Benin-Nigeria shields. It is an array of curved shear zones, curving away from the TS-TB lineament, defining an imbricate fan of NNE-trending diverging continental scale shear zones. This feature behaved as a lithospheric keel during the opening of the South Atlantic.

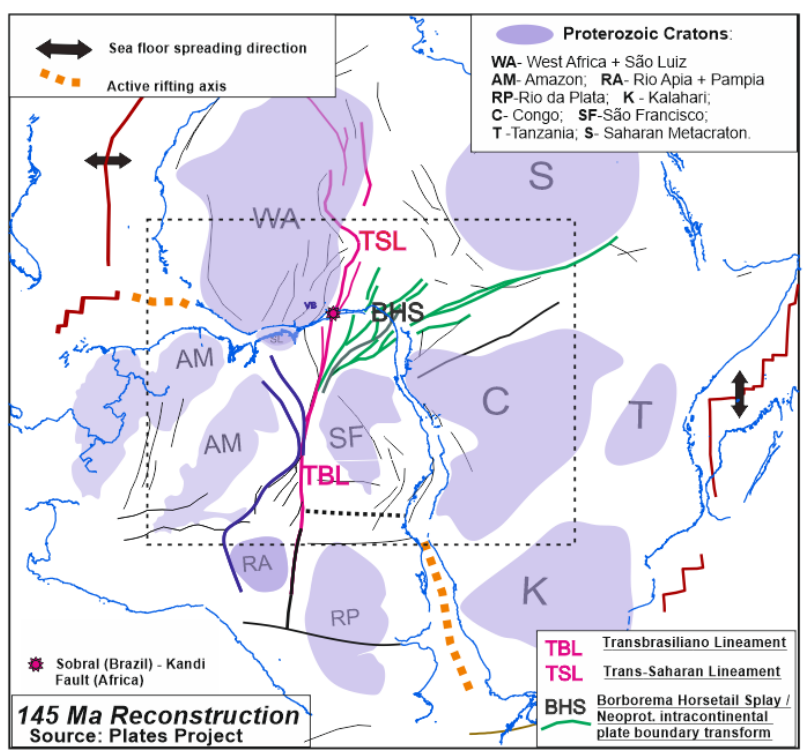

Figure 1 - Late Jurassic/earliest Cretaceous (145 Ma) plate reconstruction emphasizing the Proterozoic heritage (main geological structures). The BHS (Borborema Horsetail Splay) is a curved array of shear zones, curving away from the TSL-TBL lineament, defining an imbricate fan of diverging continental scale shear zones.

\section{Method}

Any modeling of the South Atlantic opening always faces many challenges concerning the integration of different methodologies of dating, with different margin of error, besides reconstructions misfit, incorporating or not, 
Intracontinental deformations. Onset of rifting, rift propagation and seafloor spreading are diachronic and controlled by structural partitioning of the margins. We introduce the concept of large-scale spatiotemporal kinematic indicators. We use them to identify not just largescale displacement fields, the birth or death of rift axes, but sets of events within a basin, or region that are a direct result of movements between adjacent plates (and microplates) or magmatism underlying the basin or region. The spatiotemporal analysis starts with the recognition of structural segments (regions) that bound a group of kinematic indicators that are genetically related to a tectonic-stratigraphic event, followed by the recognition of the timing relationships between the kinematic indicators using sequence stratigraphic relationships.

\section{Spatiotemporal Tectonic Stages (space and time domains}

In the space-domain, these segments can be conveniently described by westward extension of the oceanic transform faults (Figures 1), from north to south are: Segment 1: Dextral Equatorial Domain (Doldrums to Chain FZ); Segment 2: Benue-Pernambuco Plateau Orthogonal Domain (Chain to Kribi FZs); Segment-3 - The Northern Albian Buffer Zone (Kribi to Bode Verde FZs); Segment-4- The Central compartment; Segment-5-The Southern - Aptian Buffer Zone, located between St. Helena and Rio Grande-Walvis / Florianópolis FZs. Basins inboard of segments 3, 4 and 5 make up the Central Salt Basins (CSB's, Segments 3 to 5), a Sinistral domain that encompasses the basins located between Kribi and Florianópolis Fracture Zones.

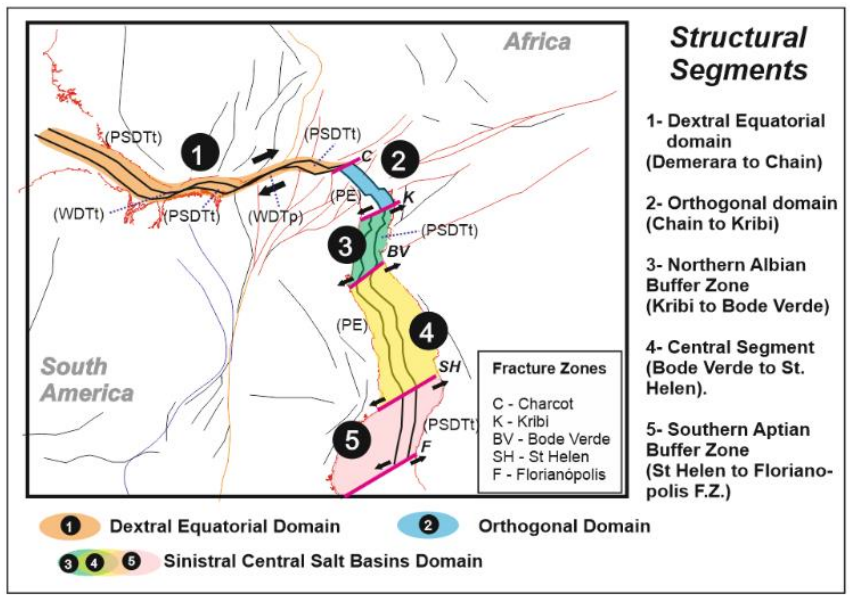

Figure 2 - Main structural segments of the South Atlantic, basically, a Dextral (Equatorial-1) domain and a Sinistral (Central Salt basins-3.,4 and 5) domain, separated by the Orthogonal Domain (2).

In the Time domain, the recognition of five Tectonic Stages was a result of sorting in time thirty-two Kinematic indicators-the bases for recognition of the time delays in the structural partitioning of the margins and the influence of Proterozoic heritage. Instead of using tectonic environmental boundaries, like pre, syn- and post-rift, we choose to recognize Tectonic Stages which are not directly recognized in the stratigraphic record (Figure 03). The vertical axis focused on the spatial domain, from Doldrums (north of Demerara) to Florianopolis Fracture Zones (south). On the other hand, the horizontal axis focused on the time span of each tectonic stage, as well as providing key observations regarding depositional environments, continental or marine rifting and the onset of sea floor spreading.

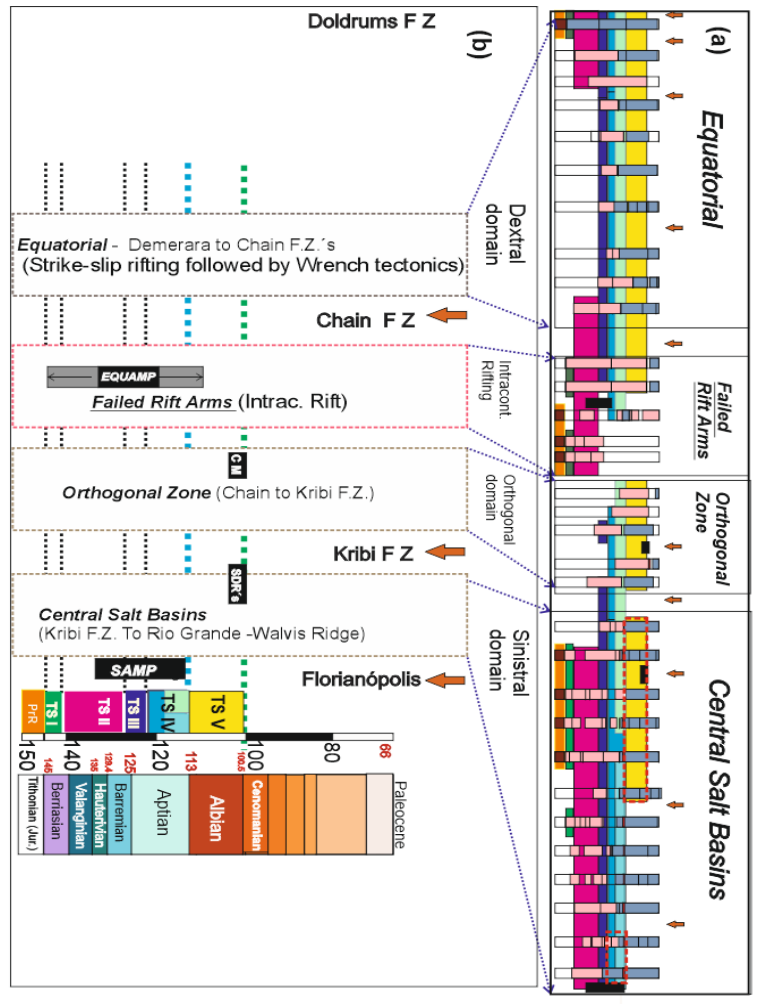

Figure 03. Interpreted main structural domains separated by fracture zones (red arrows). The figure illustrates very un-zoomed simplified stratigraphic charts of Brazilian and African basins (small horizontal, colored rectangles), and the interpreted Tectonic stages (TS I to TS V).

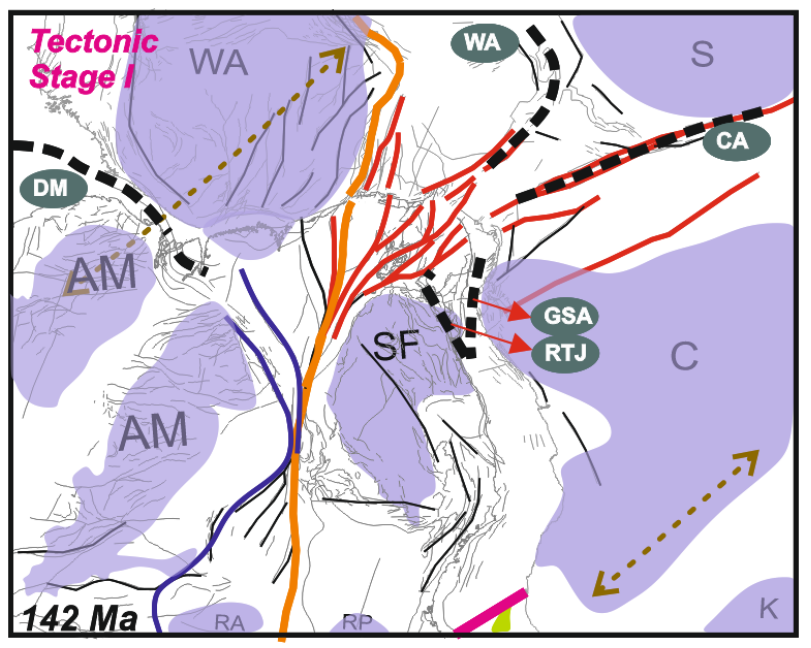

Figure 04. Tectonic Stage I. Schematic figure of the South Atlantic Ocean at 142 Ma shows intracontinental rifting axes, with the main Proterozoic features and the location of active rift axes. Rifting was triggered at the southern border of the Borborema Horse Splay 
(Pernambuco Shear Zone), and inside Africa. Onshore fault interpretation modified from the Commission for the Geological map of the World (CCGM/CGMW) maps of South America (Cordani et al., 2016) and Africa (Meghraoui, 2016), digitized and edited Krueger et al., in prep.

Tectonic Stage I: Rifting was limited to the southernmost tip of the propagating rift axis (from the Central Atlantic at the Demerara-Marajó rifts); The West and Central African rift system (WCARS) and the Recôncavo-TucanoJatobá/Gabon-Sergipe Alagoas rift axes (RTJ/GSA) south of the Orthogonal Zone (Figure 04).

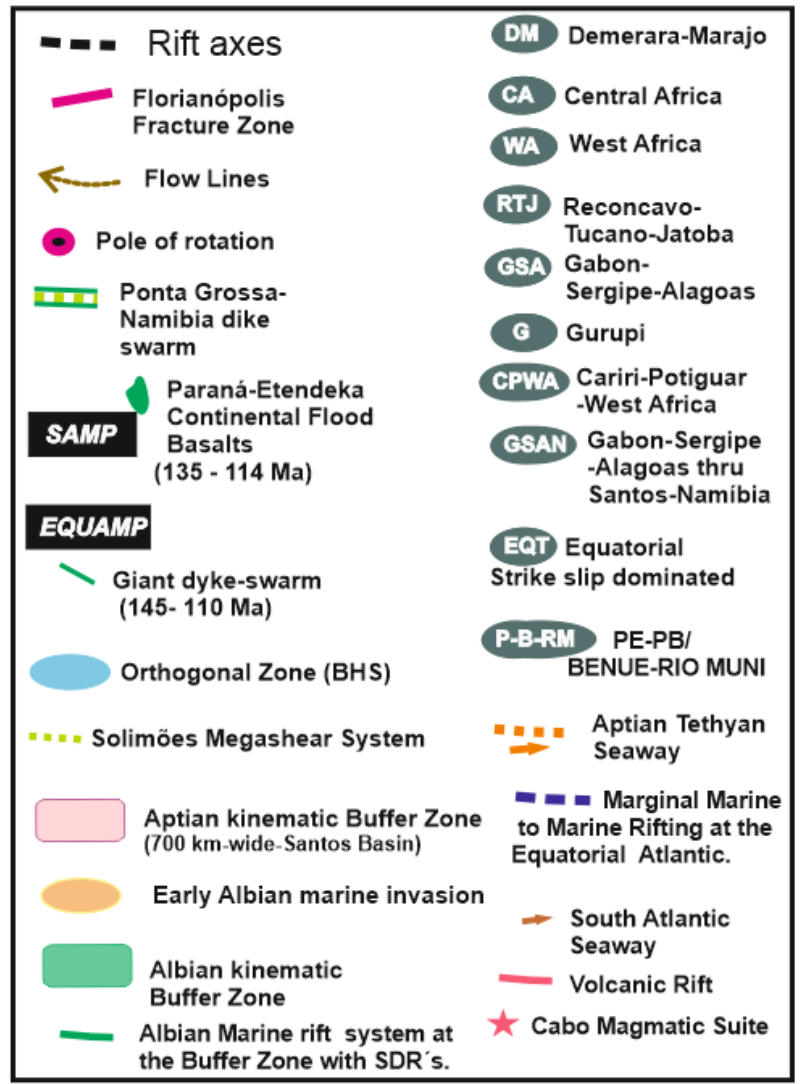

Figure 05. Main acronyms used at figures 06 to 10.

Tectonic Stage II:

- Rift axis propagated southward,

- Early Cretaceous South Atlantic Magmatic Province (SAMP).

- Clockwise rotation of South America about a pole near the tip of the Marajó rift axis (North Brazil.

- The West African Craton starts to split from its southern tip, beginning the individualization of the São Luiz Craton in Brazil and formation of the Gurupi Graben system. Intracontinental rifting between the Amazonian and the West African Craton, with the development of the MarajóDemerara rift axis.

- The birth of the Cariri-Potiguar-West Africa rift axis, formed as the West African rift system propagated eastwards, opening the way towards the Cariri-Potiguar rift axis in Brazil, which is part of the Northeast Brazilian Rift System (NBRS, (Matos, 2000).
- The Rio Ceará Mirim dike swarms are located east of the TBL-TSL, within the BHS. The Mesozoic Equatorial Atlantic Magmatic Province (EQUAMP) comprises the Sardinha, Rio Ceara Mirim and Riacho do Cordeiro dyke swarm with ages 40Ar/39Ar between 145 and $110 \mathrm{Ma}$ (Macedo et al., 2017).

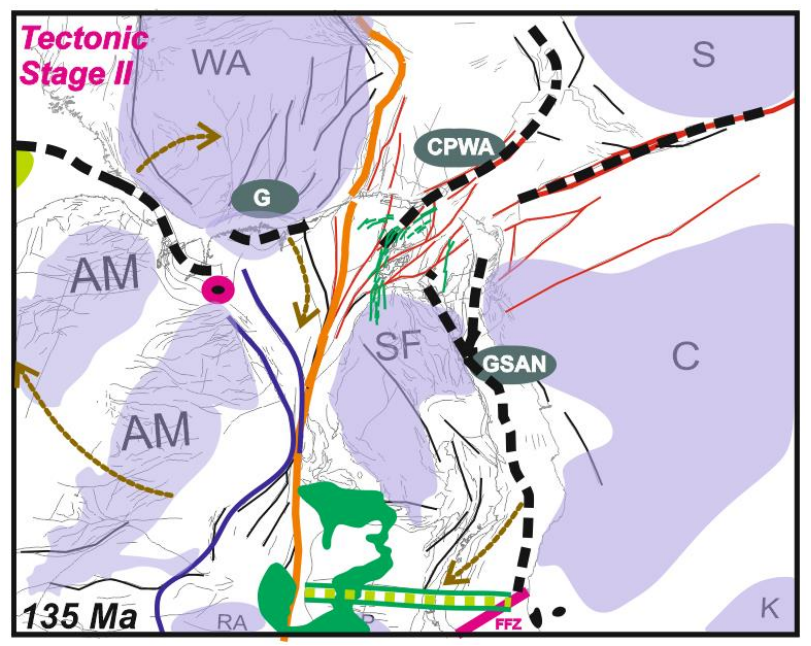

Figure 06. Tectonic Stage II- Main active rift axes, as well as the location of the Early Cretaceous South Atlantic Magmatic Province-flood basalts and dike swarms (SAMP). Two magmatic provinces are relatively synchronous: The SAMP (135-114 Ma, Szatmari and Milani, 2016) and the EQUAMP a huge dyke-swarm mainly within the Borborema Province, with ages between 145 and $110 \mathrm{Ma}$ (Macedo et al., 2017), or approximately between 135 and 120 Ma (Hollanda et al., 2018).

\section{Tectonic Stage III:}

- All onshore rift basins in Brazil and Africa get aborted.

- The clockwise rotation of South America continues, now with a new pole of rotation, located where the TSA meets the TBL shear zone and an intracontinental dextral strike slip system develops at the Equatorial Atlantic

- The continuation of the clockwise rotation of South America led at this time to the collision of the Demerara and Guinea plateaus. Casey et al. (2015) and a leftlateral shearing at the Pisco-Jurua Fault (Szatmari and Milani, 2016), also described by Caputo (1991) as Solimões Mega Shear System (Figures 01 and 13).

- The Borborema Horse Splay (BHS) acted as a largescale transfer zone, hindering rift propagation, acting as a relay zone, to balance the continuous widening of the CSB's in the South, at its main rift stage, and the strikeslip deformation in the Equatorial Segment. This new, continental-scale strike slip system sliced orthogonally the West African Craton and Pan-African fold belts, to find its way to mechanically balance the propagating rift tips of the South Atlantic and Central Atlantic

- SAMP and EQUAMP still actives. A gigantic dyke swarm of about $700,000 \mathrm{~km}^{2}$ was developed within the Borborema Province (BHS) named by Hollanda et al. (2019) the EQUAMP. 


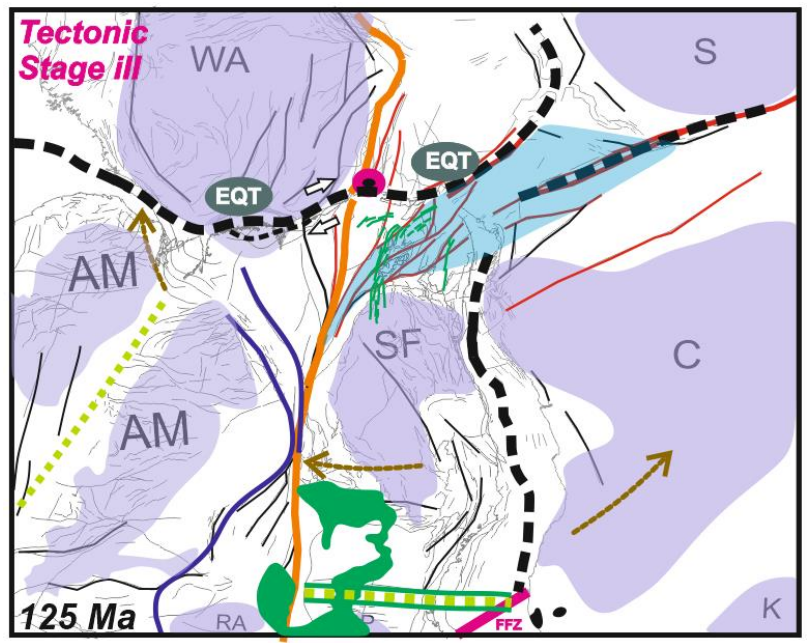

Figure 07. Tectonic Stage III. Simultaneous magmatic activities: the Atlantic Magmatic Province-flood basalts and dike swarms of the SAMP and the huge dyke-swarm of the EQUAMP. The lithospheric boundaries within the future Equatorial Margin begin to de defined, with strike slip movements, cutting across a lithospheric keel: the TSLTBL lineament. No rifting inside the Orthogonal Domain (rifting axes diverged away from the BHS.

\section{Tectonic Stage IV a:}

- For the first time, rifting was taking place at the Equatorial and South Atlantic at the same time. The lithospheric limits between Africa and South America begin to be defined.

- Widespread strike slip dominated rifting occurs in the Equatorial domain, with the fragmentation of the southern tip of the West African Craton (São Luiz Craton, in the Brazilian side).

- The Equatorial rupture occurred simultaneously with the triggering of intracontinental rifting at the Orthogonal Zone (OZ), when the continent-scale lithospheric roots of the BHS were orthogonally sliced through, forming the Pernambuco-Paraíba/Benue-Rio Muni (P-B-RM) rift axis.

- Aray (2014) published a paleontological study demonstrating a Tethyan seaway at Northeast Brazilian basins, linking Equatorial sea waters with Sergipe Basin Figure 09).

- However, at the CSB's compartment, the northward rifting propagation was delayed by a lithospheric Keel: The Orthogonal Zone (BHS), providing the boundary conditions to a buffer zone at the Segment 5 (SantosNamibia block). The Aptian Buffer zone was first described as the "Buffer Zone" by Moulin et al. (2010) act as a planet scale relay zone, balancing mechanically hyper-extended terrains of the Santos-Namibia block, with the northern part of the CSB's. Here we recognized that the Aptian Buffer zone is only one of a few lithospheric anchors that delayed continental rifting. The entire South Atlantic branch was anchored at the Orthogonal Zone/BHS (rift tip at the Pernambuco Lineament shear zone), which behaved as a large-scale transfer zone, hindering rift propagation. Therefore, there is a genetic connection between the Aptian Buffer Zone and the Orthogonal zone, and with the tectonic evolution that led to the huge pre-salt reserves.

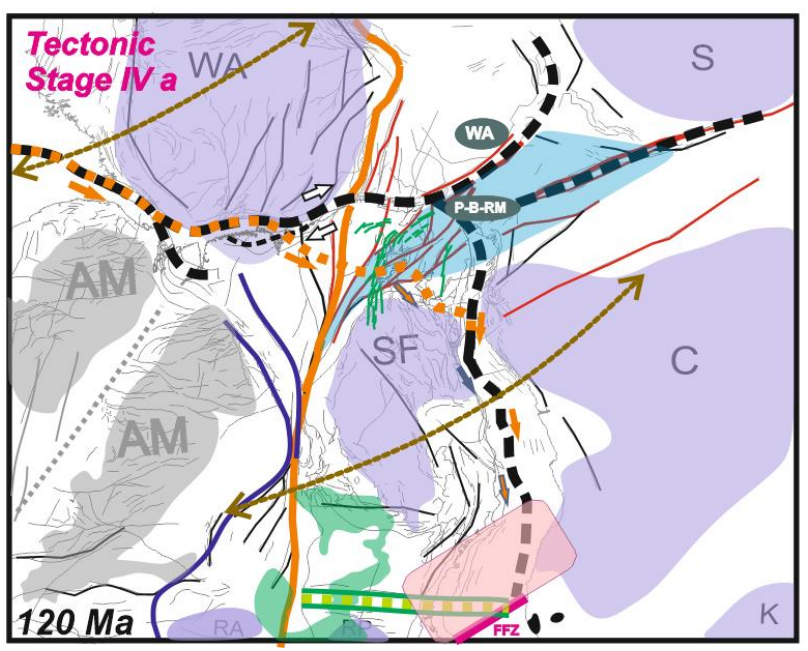

Figure 08. Tectonic Stage IV a. The Aptian Buffer Zone (pink) Clockwise rotation of South America leads to high extension rates at the southernmost part of the CSB's.

Tectonic Stage IV b:

- The lacustrine microbial sag basin evolved towards a wider endorheic salt basin at the CSB's. (Szatmari and Milani, 2016).

- At the Orthogonal Zone an intracontinental rift environment developed through the PernambucoParaíba, Benue-Rio Muni (P-B-RM) rift axis and the West and Central African rift system. The northern tip of the CSB's basins is the future site of the Kribi Fracture Zone.

- In the Equatorial domain, the environment of deposition was restricted marine, and isolated rifts formed under a sinistral strike-slip rifting tectonic regime.

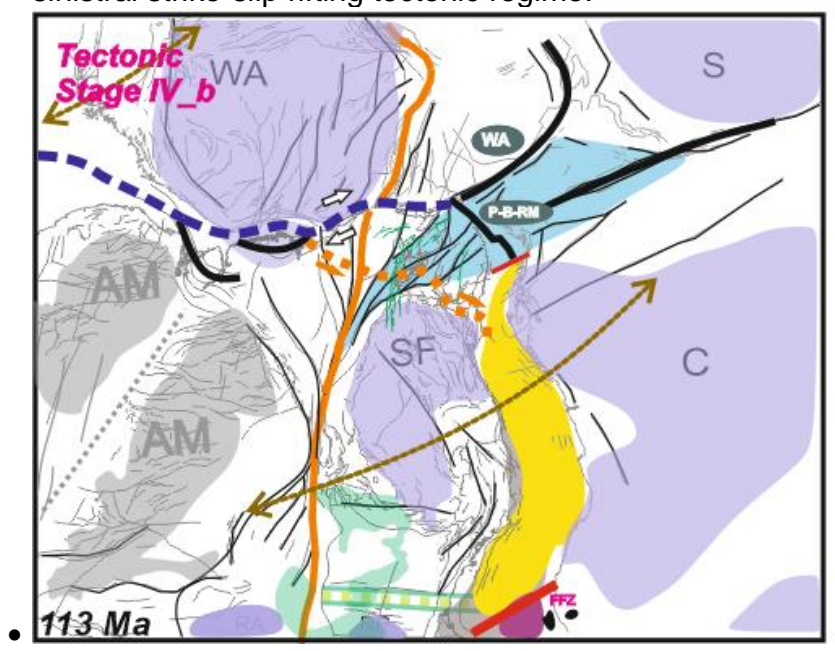

Figure 09. Tectonic Stage IV b. Salt Age-synchronous with active rift axes in the Equatorial Margin and Africa. Hypersaline conditions at the CSB's. Intracontinental rifting started at the Orthogonal Domain. The solid black line indicates the location of simultaneous continental rifting. 


\section{Tectonic Stage V:}

- Proto-transform Faults, prior to Seafloor Spreading, developed at the Equatorial Atlantic during the final stages of continental breakup. Localized sea floor spreading started at the Pure Shear Dominated Transtension (PSDTt) segments of the Equatorial Atlantic, while Wrench tectonics (transpressional and transtensional) prevailed in other basins of the Equatorial Atlantic.

- These conditions contrast with the Central salt basins (CSB), where sea floor spreading started outboard of this segment, establishing fully open marine conditions and the deposition of carbonate sequences (Early Albian Marine invasion).

- At the Equatorial Atlantic, rifting and marine water invasion continued, followed by the dynamic emplacement of fractured swells as proto mid ocean ridges, the creation of oceanic crust and the onset of transform shearing between South America and Africa (Matos et al., 2000, 2005, 2018). Oceanic crust formation started in disconnected spreading centers, separated by continents and strike-slip-faults.

- The last rheological obstacle towards the final lithospheric separation between Africa and South America was the Orthogonal Domain (BHS), where continental rifting was still taking place. However, strain was not homogeneous. The Pernambuco Lineament defines the boundary between the Pernambuco and Paraíba Sub-basins, and it is the northern most occurrence of volcanic centers. The Paraíba/Benue segment of the $\mathrm{OZ}$ (between Chain and Cameroon Fracture Zones) is a classic example of a sharply necked margin, even though it is a classic narrow magma-poor margin (Matos et al., 2004, 2018). On the other hand, the Pernambuco/Rio Muni segment of the OZ/BHS (between the Cameroon and Kribi Fracture Zones) is wider and probably a hyperextended margin.

- On the other hand, the Pernambuco/Rio Muni segment of the margin had remarkable magmatic activities synchronous with its rift phase, genetically linking the Cabo Magmatic Province, documented by the onshoreexposed Ipojuca Magmatic Suite (Sial et al., 1988, Nascimento 2003).

- The Albian Buffer Zone: The northern tip of the CSB's acted as another, younger relay zone, balancing extension south of the Orthogonal Domain. It is a good example of deep-water rifting in hyper-extended continental crust, simultaneous with sea floor spreading basin ward, documented by dated Albian-Cenomanian volcanics interbedded with marine rift sediments in the Sergipe-Alagoas basin (Caixeta et al., 2014). This may be an example of Initiation of a Proto-transform Fault Prior to Seafloor Spreading, during the final stages of continental breakup, like described by IIIsley-Kemp et al. (2018).

The Equatorial splitting evolved during the AptianCenomanian interval. The dynamic juxtaposition of continental crust against oceanic crust or spreading centers on the opposite side of a transform fault caused diachronous deformation, recorded on the sedimentary record as important unconformities, amplified or not by synchronous eustatic sea level variations (Matos, 2005). Even though full continental separation would have been achieved during the late Albian, plate tectonics interactions and lithosphere dynamics still influenced the Equatorial basins during the Cenomanian.

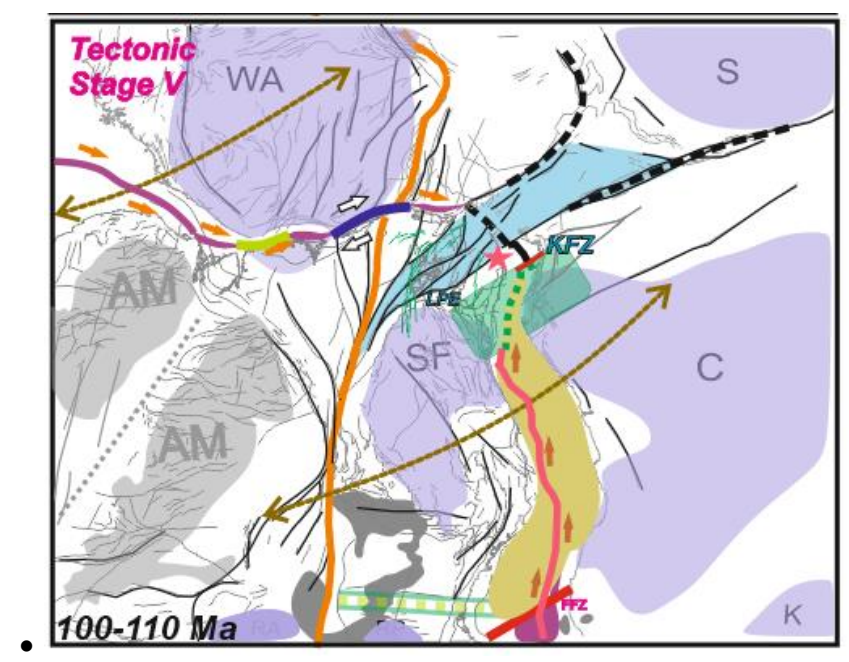

Figure 10. Tectonic Stage $V$. Location of active intracontinental rifting axes, equatorial spreading centers, volcanic and non-volcanic rift axes, while an Early Albian marine invasion occurred at the CSB'S: LPE: (Pernambuco Shear Zone); KFZ (Kribi Fracture Zone). The solid blue line indicates the location of Wrench Dominated Transpression (WDTp).

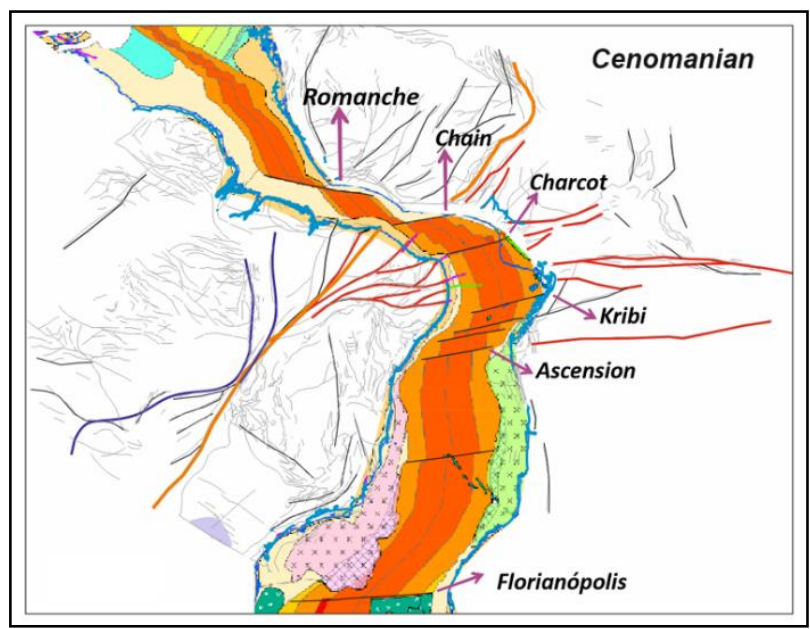

Figure 11. Schematic figure of the South Atlantic Ocean during the Cenomanian, with the main Proterozoic features and the location of active sea floor spreading and fracture zones.

\section{Final Remarks}

Intracontinental deformation was important during lithosphere and plate dynamics interactions during Mesozoic rifting. A complex net of Neoproterozoic mobile belts, and their associated continental-scale shear zones acted preventing and postponing the link between neighbor's rift branches, as well as accommodating early clockwise rotations of South America with respect to Africa, long before setting lithospheric plate boundaries.

The Orthogonal Zone (OZ) BHS) represents a large continent-scale lithospheric root, roughly east-west, 
orthogonal to the rift propagation. This region repeatedly behaved as a large-scale relay zone, and have been a major obstacle to the northward propagation of the CSB's. The oldest rift valleys are in the surroundings of the BHS and the youngest rift valleys are located within the Orthogonal Zone (OZ).

It is possible that this orthogonal zone exerted a profound influence on deformation rates at far distant basins, due to its rheological characteristics and strategic position, linking the Equatorial and South Atlantic rift branches, it became responsible for two buffer zones, and indirectly responsible for the outcome of world-class proliferous associated basins.

The oldest rift axes, the RTJ-GSA and the WCARS rift axes, developed a few thousands of kilometers away, in each direction, from any active rift or ridge (at that time, the southernmost ridge tip of the Central Atlantic Ocean, and the northern tip of the South Atlantic ridge). What triggered these oldest rift basins, which were developed in and around a major lithospheric root, the OZ/BHS has been subject of debate for many years. The recognition of giant dike swarms at the Borborema Province (EQUAMP, Hollanda et al., 2019), Albian volcanics interbedded with marine rift sediments in the Sergipe-Alagoas basin with SDR's (Caixeta et al., 2015), and a mantle source of the Cabo Magmatism (Nascimento, 2003) strongly suggest the presence of a hot mantle upwelling or plume at the Orthogonal Zone, Borborema Province.

The five Tectonic Stages were recognized through thirtytwo kinematic indicators. We use kinematic indicators as a tool to investigate the interactions between lithosphere dynamics and plate tectonic controlled rift propagation, at volcanic and nonvolcanic margins. The rift is diachronic, and so is the insertion of oceanic crust, leading to development of distinct buffer zones in space and time.

The inherited structures controlled the location of breakup under a multifaceted way:

- At the Dextral-Equatorial domain, cratons and orogenic fold belts were sliced orthogonally through by breakup, and the upper crustal heritage had minor control on basin architecture. There is no record, or minor, syn-rift magmatism throughout the Equatorial Margin.

- On the other hand, at the Orthogonal Zone there are strong evidences of a gigantic dyke swarm developed within the Borborema Province (Hollanda et al, 2019). Even though it has been named Equatorial Magmatic Province, it is not physically located at the Equatorial margin. However, like the Equatorial Margins, cratons and orogenic fold belts were sliced orthogonally through by breakup, and the upper crustal heritage had minor control on offshore basin architecture. However, at the aborted onshore rift basins, upper crustal heritage had major control on rift architecture.

- At both domains, control of the inheritance is expressed at the time domain, delaying or postponing rift dynamics until a continental-scale strike slip system could find its way to mechanically balance the propagating rift tips of the South Atlantic and Central Atlantic.
- On the other hand, at the Sinistral Central Salt Basins Domain, control of the inheritance is expressed in the space-structural domain, as observed at the northern tip of the South Atlantic propagating rift/ocean.

\section{References}

Arai, M. (2014). Aptian/Albian (Early Cretaceous) paleogeography of the South Atlantic: a paleontological perspective. Braz. J. Geol. vol.44 no.2 São Paulo.

Brito Neves, B. B., Fuck, R. A., Pimentel, M.P. (2014), The Brasiliano collage in South America: a review. Brazilian Journal of Geology, 44(3): 493-518.

Caixeta, J. M., Ferreira, T.S, Machado Jr, D L, Teixeira, J L, and Marco A. T. Romeiro, M A T (2015). O desenvolvimento da margem rifteada vulcânica albiana no Nordeste brasileiro e seu perfil para a geração de petróleo. B. G.. Petrobras, Rio de Janeiro, v. 23, n. $1 / 2$.

Cordani, U. G., Pimentel, M. M., Araujo, C.E.G., Fuck, R. A. (2013), The significance of the Transbrasiliano-Kandi tectonic corridor for the amalgamation of West Gondwana. Brazilian Journal of Geology 43, 583-597.

Hollanda, M. H. B. M., Archanjo, C. J., Macedo Filho A. A., Fossen, H., Ernst, R. E., Castro, D. L. de, Melo, A. C. and Oliveira, A. L. (2019). The Mesozoic Equatorial Atlantic Magmatic Province (EQUAMP). A New Large Igneous Province in South America. In book: Dyke Swarms of the World: A Modern Perspective. DOI: 10.1007/978-981-13-1666-1_3.

Macêdo, A. A. de,Hollanda, M.H., Archanjo, C.J., Castro, D. L., Melo, A C C. (2017). A Província Magmática do Atlântico Equatorial (EQUAMP), NE do Brasil. X International Symposium on Tectonics,22 a 24 de maio de 2017,. Salvador - BA - Brasil.

Matos, R. M. D. de, (2000), Tectonic Evolution of the Equatorial South Atlantic. Atlantic Rift on Continental Margins, AGU Geophysical Monograph 115. Edited by W. Mohriak and M. Talwani. 354p.

Matos, R. M. D. de, Medeiros, W. E. and Jardim de Sá, E. J. (2004), The Pernambuco-Paraíba Basin: AUnique Example of Extensional Deformation in the Northeastern Brazilian Margin. Inter MARGINS Workshop: "Modeling the Extensional Deformation of the Lithosphere" (IMEDL) Pontresina (Swiss Alps), July $11-16$

Matos, R.M.D. (2005). Petroleum Systems Related to the Equatorial Transform Margin: Brazilian and West African Conjugate Basins. In: Post, P., Rosen, N., Olson, D., Palmes, S.L., Lyons, K.T., Newton, G.B. (Eds.), Petroleum systems of divergent continental margin basins. Tulsa, Gulf Coast Section, Society for Sedimentary Geology, pp. 807-831.

Matos, R. M. D., Norton, I., Krueger, A., Casey, K., (2018). South Atlantic Rift Segmentation from Demerara to Walvis: The Interplay between Strike Slip Deformation and Rifting. Search and Discovery Article \#30576 (2018). Posted September 17, 2018.

Nascimento, M. A. L. (2003). Geologia, geocronologia, geoquímica e petrogênese das rochas ígneas cretácicas da província magmática do Cabo e suas relações com as unidades sedimentares da Bacia de Pernambuco, NE do Brasil (Tese de Doutorado). PPGG, UFRN, Brazil, 264 p.

Szatmari, P, Milani, E.J. (2016). Tectonic control of the oil-rich large igneous-carbonate-salt province of the South Atlantic rift. Marine and Petroleum Geology 77, 567-596. 